\title{
LEARNERS' PERCEPTIONS CONSTRUCTION ON ENGLISH BEFORE LEARNING IN KAMPUNG INGGRIS: A SOCIAL CONSTRUCTIVIST STUDY
}

\author{
Muhammad Subhan Fikri, \\ Yogyakarta State University \\ muhammadsubhanfikri@gmail.com \\ Widyastuti Purbani \\ Yogyakarta State University \\ widyastuti_purbani@yahoo.com>
}

\begin{abstract}
This paper (1) explores learners' initial perceptions of English, and (2) explains the development of the perceptions before coming to Kampung Inggris. This paper is based on ethnographic research using interpretivism as a paradigm to understand the learners' perceptions. The research site was Kampung Inggris TulungRejo village, Pare, Kediri, East Java. The participants were the students in the village. The data were collected through interview. The data were analyzed using iterative model from Miles, Huberman and Saldana (2013). In this model, data condensation, data display and conclusion drawing/verification were used to analyze the data. In the data analysis process, multiple coding and categorizations were used to figure out patterns. The theoretical framework was used in data interpretation. This study found out that (1) the learners' initial perception on English varied according to their experiences. Most of the perceptions before coming to Kampung Inggris were negative. These perception were affected by the learners' learning process, the environment and the surrounding people. In the learners' reality, English was viewed merely on its intrinsic feature. (2) The learners' perception was developed due to their life experiences. After experiencing some turning points, they believed that English was important for their lives. This change of perception also changed their attitude and became their motivations in learning English in Kampung Inggris.
\end{abstract}

Keywords: students' perception, perception construction, perception development, Kampung Inggris, social constructivist

\section{A. INTRODUCTION}

$\mathrm{P}$ eople may perceive English as a language differently. For 1.75 billion people English users (British Council:2013), this language is considered a fundamental part of their lives. It is because they are not able to run their lives perfectly if they suddenly lose their English ability. On the other side, for the rest of the population, non-English users, for example Kyrgyz or Dayak people who live on mountains, English may be perceived differently. English has no role for them, because most of them do not need English for their lives. They do not speak English with their society or earn money using the language. Their lives are perfectly fine even if English suddenly disappears.If a Dayak mangoes to U.K.,there will be a really big probability that English becomes more important for this individual, because he has to use English to communicate with people. The change of his circumstance develops his perception. The Dayak man, who initially thinks that English is not important, 
believes that English is very important after moving to a different part of the world. This example shows how a perception on a thing can be perceived differently by different people with different circumstances as what Berger and Luckmann (1991) and Burr (1998)believed. They state that reality is shared by people as an intersubjective world, where individuals share the world with others. This reality or knowledge about the world is constructed through social interaction experienced by the people.

In Indonesia, English as a language may be perceived differently too. In the current condition, when technology and globalization influence people's lives, the need of communication with other people from other countries, and the need of a language that can connect Indonesians with people from other countries are emerged. It can be seenon how much Indonesian parents invest for their children English education, not only in big cities but also small villages. This view on English is reported by Setiawan (2015) who conducted a study on parents and students' perception on English. He reports that both groups viewed English as an International language. They also believed that English can provide study and job opportunity, and access to knowledge, particularly western knowledge. Lastly, it is reported too that both parents and students believed that it could be a sign of social status. Besides the parents and the students, the teachers also share the same view about English. Zacharias (2003) reports that the majority of his respondents, English teachers, viewed English as a key to get higher social status and better works. They also perceived English as a requirement that was imposed by more globalized world. They believed that, without English, people in Indonesia would not be able to compete and be left behind.

One of the famous places for English learning in Indonesia is Kampung Inggris, a group of English courses located in Pare Kediri, East Java. There are a lot of students from places around the country coming to Kampung Inggris.According toHidayat, Surjono and Kurniawan (2011), there are about 3500 students who learned in the village. It is very interesting to explore the students'initialview on English since the village is located quite far from big cities, and the learners come from various places in Indonesia and its neighboring countries. The students who come to the village must sacrifice things in order to learn there. By sacrificing things, it means that English is meaningful for them, and these meanings are able to push them to do more in language learning. Based on the gigantic number of students who study in the village, and the costs spent to study there, the researcher conducted a research to understand and learn about how the learners view English before coming to Kampung Inggris, and what kind of experiences that pushes them to study there. 
This paper supposed to: (1) reveal the students' initial perceptions on English before coming to Kampung Inggris, and (2) explore about the development of the perceptions and learning attitude in relation with the social factors experienced by the students. Therefore, the readers can learn about the construction process of the learners' perceptions on English in their experiences, and the effects of this perceptions toward their learning attitude. In order to achieve the objectives, the study was addressed by the following research questions.

1.What are the initial perceptions of learners before coming to Kampung Inggris?

2.How are the learners' perceptions shaped and developed through their social experiences?

\section{B. REVIEW OF LITERATURE}

\section{Previous Research}

The example of different meaning of English for different people can be seen from the explanation coined by Despagne (2010) about the perceptions on English from Mexicans. In one side, the positive perceptions, English referred to international business possibility, lingua franca, development of technology, communication, bilingual education and possibility of overseas study, higher incomes, more respect and power. These factors built positive meanings for the ones who wanted to achieve such things. But, on the other side, Despagne, referring to Chasan and Ryan' study with UNAM students in 1995, mentions that English was perceived negatively by Mexicans as a reference to US imperialism. Other factors mentioned by Despagneare immigration and border problems, racism and discrimination, dominant and dominated, North American business and product invasions, etc. Despagne also adds that for the pupils in a rural school in a little village near Puebla, English was perceived as a survival tool that led them to better incomes. But, for them too, English also meant loneliness, exploitation, abandonment, hard work and discrimination, because they had to work in US as immigrants. The similar example is also reported by Çetinkaya (2009). His research found that the participants, students of DokuzEylul University in Turkey, had mixed perception toward English or the language learning. Çetinkaya mentions that the participants positively associated English with power, and economic and technology development. Even though the participants were aware of the positive meaning of the language, Çetinkaya also adds that the respondents criticized English domination and showed a negative attitude toward the English learning process. From the participants answers, it can be seen that they asked about the obligation of learning English at school, and the domination of English as a foreign language in the world and their country. They also showed their preference on their native language 
over English. From both field reports, it can be seen that even the same group of population had different and mixed perceptions toward English.

Besides the different meanings which the learners have for English, it is also important to explore what the learners do toward English with certain meanings or perceptions on the language. Alkaff (2013), in his research finding, states that the students, his research participants, had no doubt on the importance of English. They mentioned that it was important to learn English if they want to travel across countries. Then, all of them admitted that English could help them in getting better working opportunities. Lastly, the participants also stated that the language was significant for their education, undergraduate and post graduate programs. This good perception was linear with the students learning attitude. In the same research, Alkaff mentions that almost all of the participants believed that they could improve their English. This statement was followed by showing their confidence in improving their language skills. Besides their confidence, the students also felt that more sufficient practice and good learning environments were needed to learn English better. In order to improve their skills, the students also explained that they actually did more efforts like reading and watching English movies. Interestingly, some of the respondents said exactly the opposite of other participants. The students admitted that if they had desire or motivation to learn, or loved and liked the language, they could learn English better. However, even if it is oppositional, the statement still confirms how meanings or perceptions on English influenced the students' actions toward the language.

The effect of meaning into the action of the students are also mentioned by Perez-Gore, et al. (2014). In their research, they believe that there is a strong motivation for learning and teaching English which possibly gave positive effects to the teachers' attitude towards their profession as well as students' attitudes towards their learning process. In different research, Jimenez (2017) concludes that the participants language performance was affected by lacks of commitment, motivation, interest and effort in studying English. Some of them even stated that they lacked in giving the importance and devotion toward English. Therefore, based on these studies, it can be understood that a meaning on English influenced the students' attitude or actions toward the language. The positive views of the language led to positive actions, and vice versa.

\section{Social Constructivism and Symbolic Interactionism of Reality}

The phenomena of the construction and development of meaning, knowledge or reality is mainly discussed by social constructivists. Social constructivism is centered in exploring 
about how the world is constructed through social settings. Onuf (2012) and Andrews (2012) explain that social constructivism is used to study social relation as a frame to understand the world or the reality. This understanding is a knowledge or meaning of something constructed through people social relations. It also means that the knowledge or meaning of something maybe changed when the social relations are changed. This point is argued by Kim (2001) who claims that if reality is believed and named based on the construction of people's perception, there would be a possibility to re-construct or develop some new values or meaning in the reality. This explains what happens in the example about Dayak man in the beginning of this article. When a person's life condition is changed, the perception about or the meaning of English may be changed too.

Other than social constructivism, symbolic interactionism also discussed the issue which involves the construction of meaning in individuals' reality. There are three main tenets of symbolic interactionism proposed by Mead (in Blumer, 1969; Burbank and Martins, 2009; Dennis, 2011; Jeon, 2004; and Lichtman, 1970). They are:

1. Individuals or human beings act toward things or the world based on the meaning of the things for them.

2. The meaning of the things or the world is resulted or emerged from social interactions that the individuals have with others.

3. These meanings are dealt and developed through a process of interpretation used by the person in handling the things that the individuals experience in their reality.

In these principles, Mead emphasizes that every single person acts in the world always with consideration of the meaning of the things that becomes the object of the actions. This meaning or knowledge about the world is derived from the individuals' social interaction with other people around them. He also emphasizes that in handling and developing the meaning, the individuals use interpretation of the experiences they had in the social interactions. By this explanation, it can be concluded that people act differently toward English or English language learning because English has different meaning for them. For Dayak people who still live on a mountain, English has no meaning, because it possesses no function on the social interaction among them, but for the same Dayak people who live in UK, English is used every day for communication with other people. It means that, English becomes important for them, and learning the language as an action is based on this meaning or knowledge.

The process of construction in symbolic interactionism and social constructionism is apparently similar. The first process is the construction of the knowledge through social interaction as also stated by Blumer (1969),Burbank and Martins (2009), Dennis (2011), and 
Jeon (2004)who believe that meaning is constructed continuously by human beings along the time they existed, because human beings always have interaction among them. This statement is similar with what Kim (2001) states about social constructivism. She believes that the reality of human beings is not an objective depiction, but a result of social construction. Therefore, from both statements, it can be understood that both social constructivism and symbolic interactionism agree that a meaning or knowledge about something is constructed initially by having a social interaction with the world.

After the process of construction through interactions, both social constructivism and symbolic interactionism also emphasize on the process which happens inside the individuals' minds. Social constructivists, Gergen and Wortham (2001), argue that a knowledge is possessed by each individual's mind. It shows that human has an internal part in owning the knowledge. This argument is supported by other social constructivists, Brooks and Brooks (1999), Wells (2002) and Amineh \& Asl (2015). They stated that knowledge is upon the understanding constructed internally by the individuals. Internal construction here means that the knowledge is understood by individuals depending on their own views or interpretations. Therefore, different persons will probably construct different knowledge or meaning on the same world or reality. This process also explained by symbolic constructionists, such as Denzin (1969), Blumer (1969), Jeon (2004). The internal process inside the persons' mind is called internal social process, self-lodging, or inner conversation. All of them imply that human beings have an internal mechanism where a discussion occurs to interpret the things experienced by them. So, after the knowledge constructed through social interactions with the world, it is interpreted or viewed by the internal process inside each individual's mind.

The discussion about how the meaning or knowledge of the world or reality perceived by human being is resumed by Searle (1995) in his layers of reality. Searle proposes that world or reality was divided based on how its features are viewed by human beings. The first is intrinsic feature. This feature represents the natural existence that is independent regardless the person who views it. The second one is observer-relative feature. This feature relies heavily on the position of the human toward the things or the world. This feature that makes Dayak people on mountains view English differently with other Dayak people who live in UK. In this feature too, Searle adds that human beings assign functions to the things. English may be assigned not only as a language for daily conversations, but also for a language instruction in a classroom. Therefore, if human beings see the observer-relative features of a thing, the individuals will assign the function of the things. Searle's layers of reality can be seen in the figure 1 below. 


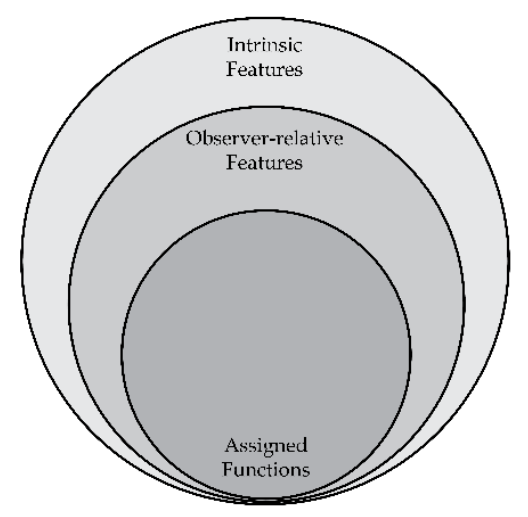

Figure 1. Searle's layers of reality Adapted from Searle (1995)

\section{METHODS}

\section{Research Design}

The research was an ethnographic research. It presented the participants' point of view on the problem, and therefore involved a close relationship with them. The study was held to record the construction process and to depict what happened with the participants (LeCompte and Schensul:2010, Lodico, Spaulding, and Voegti:2010, Fetterman:2008). It used qualitative model because the data are qualitative data and displayed descriptively. This research used social constructivism or relativism as a frame of the research. This frame was used to view and make sense the findings (LeCompte and Schensul, 2010, Harrison,2014).

\section{Research Site and Participants}

The study was conducted in Kampung Inggris, DesaTulungrejo, Kecamatan Pare, Kabupaten Kediri, East Java. It is located $27 \mathrm{~km}$ from Kediri City. It was conducted for 3 months, from March until May 2017. The participants of this research were the learners of English courses in Kampung Inggris. There were 18 learners from around the countries participating in this research. The distribution of the participants origins can be seen in table 1 below.

Table 1. Participants' Origins

\begin{tabular}{clc}
\hline No. & \multicolumn{1}{c}{ Origins } & $\mathbf{N}$ \\
\hline 1 & Aceh & 3 \\
2 & Banten & 1 \\
3 & Bengkulu & 2 \\
4 & Central Java & 2 \\
5 & East Java & 2
\end{tabular}




\begin{tabular}{clc}
6 & Jakarta & 2 \\
7 & North Sulawesi & 1 \\
8 & North Sumatera & 1 \\
9 & South Sulawesi & 2 \\
10 & West Nusa Tenggara & 1 \\
11 & Yala-Thailand & 1 \\
\hline & Total & $\mathbf{1 8}$ \\
\hline
\end{tabular}

\section{Data Collection and Analysis Techniques}

The data collection technique used in this research was interview. The type of the interview was informal conversational interview. The researcher used this type of interview because it made the participants opening up with their experiences and telling their honest perceptions (Gall, Borg and Gall:2003, Schensul and LeCompte:2013, Fetterman:2008). The data collection process was stopped after the data acquired were saturated. In ensuring the trustworthiness of the data collected, the researcher used some techniques. The research used triangulation of data sources to cross-check the data acquired (LeCompte and Schensul:2010, Rothbauer:2008), and it also uses random sampling to avoid bias in selecting the participants (Shenton:2004).

The researcher used iterative model in analyzing the data (Miles, Huberman and Saldana:2013). It followed three steps: data condensation, data display, and conclusion drawing and verification. In analyzing the data, the researcher used several coding, and the theoretical frame to interpret the patterns of the data analyzed.

\section{FINDINGS AND DISCUSSION}

\section{The Learners' Perception on English and The Language Position on Their reality}

The clearest perception from the learners is on the issue of the importance of English. The majority of the statements from the respondents indicated that they did not view English as an important thing. Half of them stated that English was not important for them. They said that they thought English was not important because they never use it for their lives. The other half, mentioned that English was not important indirectly. They told in the interview, that English was not their priority, then they chose to focus more on other subjects in the school that would be significant for their future study or works. Some of them also mentioned that their school and environment did not socialize and emphasize the importance of English in the schools. Then, some others also admitted that they thought that they did not need English. Only a really small number of the participants who mention that they actually 
realized that English is an international language. For them, it was important, but they were still bad at it.

This perception can be understood easily by viewing other statements from the participants. The participants also mentioned that they think English was hard. It is because the learners considered English as an obligatory subject which they had to pass in the end of the semester. They also believed that they had to be good at every lesson, but they said that they were only able to focus on a single subject. On the similar idea, some participants stated that if there are no other lessons in the school, English would be easy for them to learn. Since English was not their favorite subject at school, they did not learn it seriously. Then, the participants complained that English, in higher level, became harder due to the lack of basic knowledge of the language. The higher the level of their education, the harder English for them. Therefore, it can be seen how much the participants were burdened from the complaints about how hard English at school.

Based on the explanation from the participants, it can be understood that they did not only consider English unimportant, but they also considered English more as a subject, not as a language. This perception can be understood based on the participants' statements about the learning process. In the interview, they told that their teacher asked them to write down what was written in their materials books without other tasks involving further interaction. They also mentioned that their teachers asked them to answer questions in a book full of exercise, or to memorize vocabularies given by the teachers. In this learning process, English was exposed as a series of exercise, memorization, or writing activities to get score. The participants added too that their schools did not facilitate them to practice their English. None of them mentioned about activities that made the students interact with other students using English. The social activities in the class and outside the class did not lead the students to using the language as a communication tool. Therefore, it can be comprehended why they only describe it as a regular subject like other subjects.

Based on the participants' explanation, there are three scenarios that can be drawn. The scenarios can be seen in the figure 2 below. 


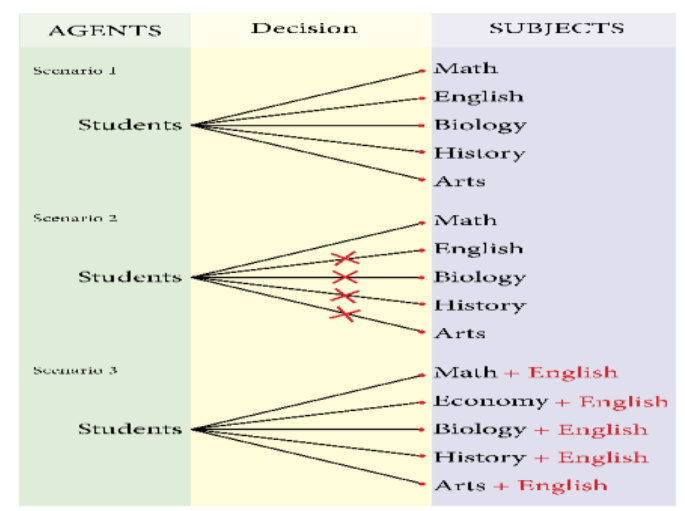

Figure 2. The Students' Perception on English in School

On the figure, the first scenario depicts the students' perception about school. The students thought that they had to pass every subject in the school. Then, the second scenario was when the students have their focus on certain subjects. This was what the students did. The students chose the subjects they favored and neglected other subjects. The last scenario is what will happen if the students perceive English as a language not only as subject. The students will realize that whatever the subjects they favor English is needed as a language of instruction.

Other factor that helped the construction of the perception was the absence of English function in the students' lives. The students stated that their teachers, other students and people around the students, never talked to them using English. Based on the statement from the participants, it can be understood that English had no function in their lives. The function of the language in any form of communication was never constructed throughout the social interaction between the participants and the people around them. Therefore, the meaning, English as a language for communication, was never constructed due to the lack of social interaction in English experienced the students.

The construction of meanings in the students' reality is what social constructivists and symbolic interactionists argue on the first tenets of reality constructions. By saying that English is same with other subject, the participants confirms that for them, the meaning of English is only limited as something to learn in school. This meaning was deeply constructed by many interactions they had with people around them, the school learning system, and themselves. None of the interactions showed the real function of English to them. Therefore, in the class, they learn English meaninglessly. These events are what Berger and Luckmann (1991) and Burr (1998) explained about the social constructivism of reality. The students shared their reality with people around them. In this case, the people are the teachers, and their friends. Because the teachers and the friends treated English as a subject, and never exhibited the communication in English, the reality constructed was that English was only a subject for them. It meant something 
which should be memorized, answered in assignment books, and written from materials books. This construction of meaning also proves the second principles of symbolic interactionism explained by Mead in Blumer (1969), Lichtman (1970), Jeon (2004), Burbank and Martins (2009), and Dennis (2011).

In reference to the construction of reality from Searle (1995). The students only recognize the intrinsic features of English. These features do not need the students' point of view to exist. In other word, whatever the perceptions from the students were, the features would not change.They learn the knowledge about the sounds, writing symbols, and the rules, but know nothing about how to use them in a real communication other than for passing the subject in the school. The position of the students' reality on English as a part of the world in Searle's layers of reality (1995) can be seen in the figure below.

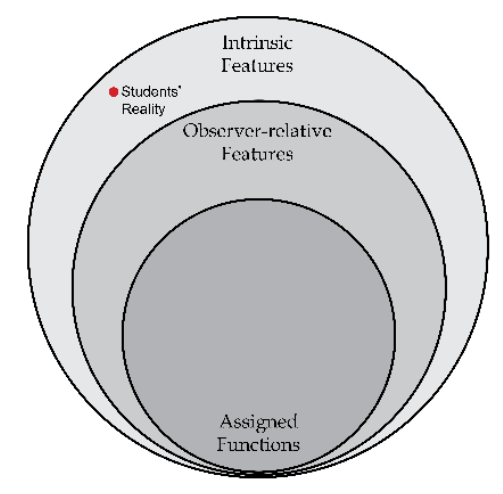

Figure 3. English in Students' Reality

Lastly, since the meaning of English for the students' reality was only its intrinsic features, English as a subject would be perceived as a burden in their school learning process. Moreover, when there are other subjects which were more meaningful for them because they favored the subjects for their future, English was considered less important thing. Therefore, with the meaning of the language constructed in their reality, the students' actions towards English while they were studying in their schools were understandable.

Based on the findings and discussion about the students' perception on English before coming to Kampung Inggris, mostly the perceptions from the students are negative. Related to the studies conducted by Chasan and Ryan in Despagne (2010), the students have the negative perceptions as well as what the students in Mexico have, but the perceptions are different because the perceptions are constructed by different factors. This difference is also found if this study is compared with the study held by Çetinkaya(2009). The students in Despagne (2010) and Cetinkaya (2009) describe their perceptions on English related to its geopolitical positions. Meanwhile, the students in this research consider English negative due to the learning process that they experienced before. 
This difference becomes clearer if the factors are analyzed. As it is found in this study, the students' perceptions were constructed by some factors. These factors were experienced by the students in their past levels of education (elementary and high school). The students in Mexico or the students in Turkey constructs their perceptions by considering something foreign (not from their country), and the consider them as a domination or even more as imperialism. Differently, the students in Kampung Inggris never give statement related to this domination, but they commented more on how the language was taught in their class. Henceforth, even if the students' perception is negative, this study found that the students' negative perceptions are constructed more by the learning process rather than the sentiment on geopolitical situation.

Hence, on the students' perception, it can be understood that language learning process and environments heavily influence the students' perceptions. In order to construct positive perceptions on English, the students' learning process and environment need to be more accommodative and supportive. This construction is relatively easier to be accomplished comparing with the construction that need to change the students' perception related to geopolitical position of English, such as what was found by Chasan and Ryan in Despagne (2010) and Cetinkaya (2009).

\section{Development of the Learners' Perceptions and Learning Attitude}

In exploring the development of the perception, the researcher asked about the participants journey that led them to Kampung Inggris. The participants answered by recounting three different experiences that then became their motivations to learn English again. The first one was that when the students in a condition where they had to acquire a good score in English proficiency test. This score was one of the requirements for them when they wanted to continue their study. The second experience was when they failed in a situation that required them to use English. For example, an admission test for university programs, or when the students had to read course materials in English and were not able to learn it effectively due to the language barrier. The last experience was when the participants wanted to get a good working position. For them, in order to get better income by having a good working position, the only way was to have good English skills. This statement from the participants were similar with the findings of the researches conducted by Çetinkaya (2009), Despagne (2010), and Alkaff (2013). English was perceived positively by the students or have a good meaning for them in its relation to power, chances, development, and better life.

What actually changed or developed in the students' reality was not the meaning. The meanings of English, or the students' perceptions, were practically the result of the changes in the students' reality. Initially, their lives were perfect regardless the existence of English as language. 
But there were eventually some points where they faced a different reality that forced them to accept that English had a function in their lives. These changes were reflection of the interpretation from the students on the experience they had. The changes confirmed the internal process explained by Gergen and Wortham (2001), Brooks and Brooks (1999), Wells (2002), Amineh and Asl (2015), Denzin (1969), Blumer (1969), and Jeon (2004). After conversations inside their minds, by comparing the existed knowledge, and new knowledge constructed through the latest experience, the students changed their view on English. This is also what Mead's third principle elaborates about the modification of meaning that each human being does through interpretation of the experience. The participants modified the meaning of English after they experienced different reality. They realized that eventually English had an integral part in their future. They need English in order to be accepted by universities, to avoid another failure, and to get a good or better job. These turning points became their motivations in learning English again after graduating. They sacrificed a lot of things for learning in Kampung Inggris. These sacrifices, such as power, money, time, etc., were the sign that English became more meaningful for them. The meaning was deeper than it was before when the students were still studying in school. Therefore, it can be concluded that these turning points exposed the importance of English to the participants. The figure below shows the shifted reality of students in viewing English as a part of their lives.

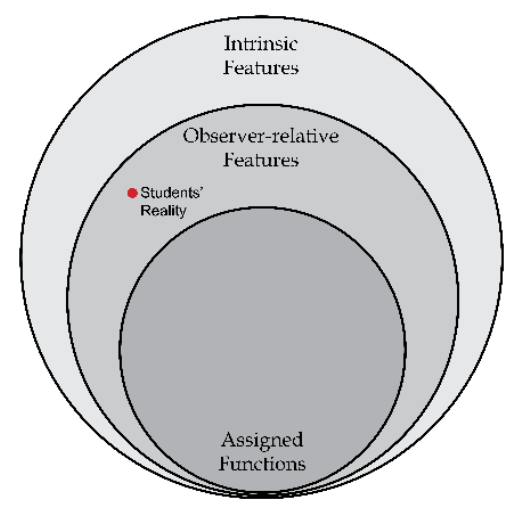

Figure 4. English in Students' Shifted Reality

It can be seen in Figure 4 that the students' reality was deeper than before. It already recognized the observer relative features of English. It means that the students had already seen the language as something meaningful for their lives. Even if they functioned it differently in their lives, such as a study or work requirement, or to avoid a failure, the language became functional therefore it was meaningful.

Regarding the learning attitude, since the students only thought English as a subject, obviously they admitted that they focused on other subjects. The students also mentioned that they did not learn seriously when they had English in the class, never had a review after learning 
the materials in the class, did not practice their skills and believed that English would not be useful for them. This attitude was a result from the students' perception on English as it is mentioned by Mead in his first principle in Blumer (1969), Lichtman (1970), Jeon (2004), Burbank and Martins (2009), and Dennis (2011). Because the meaning of English for the students was a school subject which was unimportant and burdening for them, it was clear that the students had a bad learning attitude on the learning process. This learning attitude was similar with what Çetinkaya(2009) report in his report.

The change on the meaning of English for the students also changed the students learning attitude. The students mentioned that after experiencing the turning points, their attitude in learning English was changed. The most obvious one was that they sacrificed a lot of things in order to be able to learn in Kampung Inggris. Even before that, one of the participants admitted that they started to learn English independently. The students added that in Kampung Inggris they took a lot of classes, came out of the comfort zones in order to practice their language skills, were more enthusiastic while learning in the class, and practiced more outside the class. The change of the students' learning attitude can be seen in the figure below. The percentage in the figure represents the number of the students who experienced the turning points.

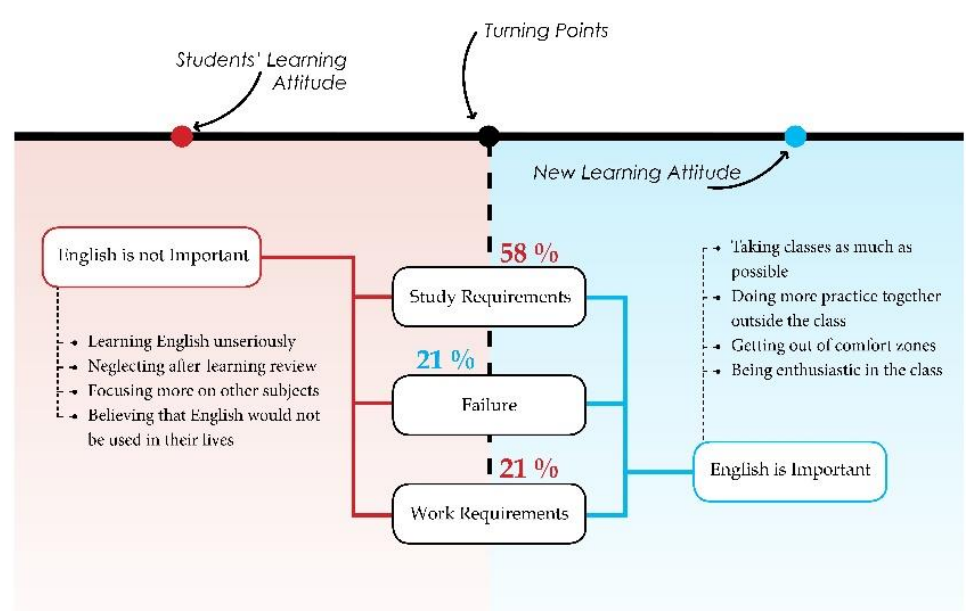

Figure 5. Students' Learning Attitude Before and After Turning Points

Based on the figure, the development of the perception and the learning attitude from the students can be seen clearly. It shows that the turning points changed the perceptions of the students on English first, then the perception changed the action of the students toward English. The action here was their attitude on the language learning process. This finding confirms the results of the study from Alkaff (2013), Perez-Gore, et al. (2014). It shows that the students who had a positive perception toward English intended to have a good or positive attitude. Oppositely, the finding also proved the research from Jimenez (2017). It confirms that the students who had a negative perception on English would likely to have a 
lack of commitment and motivation in learning English. The lack of commitment and motivation was seen in the students bad learning attitude.

Based on what were found and discussed in this section, the students' perception cannot be described a static position. Some participants stated some small good comments related to English when they met a good teacher in their school. Then, when they told their learning process in the other years with the teachers they disliked, the comments became negative again. In addition, the students, who finally decided to go to Kampung Inggris, proved this perception development. They think that English was an unimportant part of their lives before, but when they stumbled upon the turning points (failure, work and study requirement), they realized that English is important. Their perceptions were developed through this process, then the process also changed their attitude in learning English. This finding, the perception development, is in line with the third symbolic interactionism tenet from Mead (in Blumer, 1969; Burbank and Martins, 2009; Dennis, 2011; Jeon, 2004; and Lichtman, 1970). Through the social interactions experienced in the students' reality, they develop or change the meaning of English by having a process of interpretation of the interactions. Therefore, there is big possibility that the negative perceptions on English can be re-constructed or developed into a better one. This development can be accomplished by providing certain social interactions such as what the participants in this study have experienced.

The process of the development and its consequences in the students' reality are what this study dug more in Kampung Inggris, while other related researches by Jimenez (2017) and Alkaff(2013) discuss more on the linearity between the students' perceptions and their learning attitude. Alkaff (2013) found the positive perceptions influence the students positive learning attitude, while Jimenez (2017) found negative attitudes led the students into language skill deficiency. This research found that the student used to have negative perceptions on English and negative attitude in learning the language, but it also found that there was a development of these perceptions after the student encounter some life experiences related to English. Some factors changed or re-constructed their perceptions on English, and also changed their attitude toward the learning process of the language. Thus, the most important point should be taken from this question is that perception is re-constructible and this research found what might possibly can change the students' negative perceptions. 


\section{E. CONCLUSION}

The study showed that the learners' perception on English are varied based on their personal experiences. These experiences constructed and shaped the learners' perceptions. According to the findings and discussion, there are some points can be concluded. They are the construction of the learners' initial perceptions, the development of the perception, and the effects of the developments on the learning attitude of the students.

The learners initially viewed English only as a subject because they thought that they would not need English in their future. This perception was constructed through their experience on the language learning process. The learning activities that have lacks such as social dimension, unsupportive learning environments, and uncooperative people in speaking practice contributed in constructing the students' perception on English. Since the learners thought that English only as a subject and would not be used for their future, the students thought that it was unimportant. Their perception was shifted or developed after they experienced some turning points that later became their motivations in learning English again after graduating school. These turning points were study and work requirements, and also the failure that the students experienced due to their poor English. After experiencing these experiences, English became more important for the learners. It is because eventually they realized that English was very useful for their lives.

The development of the students' perceptions on English has affected the students' actions toward the language. This change can be found on their attitude in learning the language. Before the turning points, the students learned the language in an unserious manner, but after the changes, they learned English enthusiastically. The students have shown their enthusiasm in learning English by deciding to go to Kampung Inggris, choosing a lot of programs, practicing more, and coming out of their comfort zones in order to improve their skills.

Henceforth, teachers really need to consider the learning process and environment in order to develop the students' perception toward English. This research suggests the consideration on the learning process and environment since most students who participated in the interview constructed their negative perceptions through their experience of learning in school. Teacher are suggested to avoid learning process or interaction that might construct negative perceptions on the language. Even if the negative perceptions are already constructed, teachers have chances to make some actions in order to re-construct the students' perceptions. This is very important to be done by teachers since the perception may 
influence the students learning attitude, and there is a possibility that the attitude will also affect the output of their learning process.

\section{REFERENCES}

Alkaff, A. A. (2013). Students' Attitudes and Perceptions towards Learning English. Arab World English Journal. 4(2): 106-121. Retrieved July 21, 2018, fromhttp://www.awej.org/index.php/volume-4-2013/41-awej-volume-4-number-22013/284-amal-ali-alkaff

Amineh, R. J. andAsl, H. D. (2015). Review of Constructivism and Social Constructivism. Journal of Social Sciences, Literature and Languages. 1(1): 9-16. Retrieved July 30, 2018, from http://www.blue-

ap.org/j/Journal_of_Social_Sciences,_Literature_and_Languages/IssueVolume \%201\%20(2015)-Issue\%2001

Andrews, T. (2012). What is Social Constructionism? The Grounded Theory Review, 11(1): 39-46. Retrieved February 20, 2016,from http://groundedtheoryreview.com/wpcontent/uploads/2014/03/1101_01.pdf

Berger, P. L., andLuckmann, T. (1991). The Social Construction of Reality: A Treatise in The Sociology of Knowledge. London, UK: Penguin Books Ltd.

Blumer, H. (1969). Symbolic Interactionism: Perspective and Method. Berkeley: University of California Press.

British Council. (2013). The English Effect: The Impact of English, What It's Worth to The UK and Why It Matters to The World. Retrieved May 23, 2018, from britishcouncil.org/organisatoion/policy-insight-research/research/the-english-effect

Brooks, J. G., and Brooks, M. G. (1999). In Search of Understanding: The Case for Constructivist Classroom. Alexandria. Virginia: Association for Supervision and Curriculum Development.

Burbank, P. M. and Martins, D. C. (2009). Symbolic Interactionism and Critical Perspective: Divergent or Synergistic? Nursing Philosophy. 11: 25-41. doi:10.1111/j.1466769x.2009.00421.x

Çetinkaya, Y. B. (2009). Language of Others: EFL Students' Perception of And Attitude Towards English. C..Ü. SosyalBilimlerEnstitüsüDergisi. 18(1): 109-120 Retrieved July 21, 2018, from http://dergipark.gov.tr/cusosbil/issue/4381/60098

Burr, V. (1998). Overview: Realism, Relativism, Social Constructionism, and Discourse. In I. Parker (Ed.) Social Constructionism, Discourse and Realism (pp:13-26). London, UK: Sage Publication.

Dennis, A. (2011). Symbolic Interactionism and Ethnomethodology. Symbolic Interactionism. 34(3): 349-356. doi:10.1525/si.2011.34.3.349

Denzin, N. K. (1969). Symbolic Interactionism and Ethnomethodology: A proposed Synthesis. American Social Review. 34(6): 922-934. doi:10.2307/2095982 
Despagne, C. (2010). The difficulties of Learning English: Perceptions and Attitudes in Mexico. Canadian and International Education. 39(2): 55-74. Retrieved July 21, 2018, from http://ir.lib.uwo.ca/cie-eci/vol39/iss2/5

Fetterman, D. M. (2008). Ethnography. In L. M. Given (Ed.)theSage Encyclopedia of Qualitative Research Methods(Vols. 1-2)(pp. 288-292). California: Sage Publication, Inc.

Gall, M. D., Gall, J. P. and Borg, J. R. (2003). Educational Research: An introduction (7 $7^{\text {th }}$ Ed.). USA: Pearson Education, Inc.

Gergen, K. J. and Wortham, S. (2001). Social Construction in Pedagogical Practice. In K. J. Gergen (Ed.) Social Construction in Context (pp. 115-136). London: Sage Publication Ltd.

Harrison, A. K. (2014). Ethnography. In P. Leavy (Ed.) Oxford Handbook of Qualitative Research (pp. 223-253). New York, NY: Oxford University Press.

Hidayat, A. R. T., Surjono, and Kurniawan, E. B. (2011). PengaruhKeberadaan Kampung InggrisTerhadapGunaLahan dan SosialEkonomi Masyarakat di DesaTulungRejo dan DesaPelem, Kabupaten Kediri. Jurnal Tata Kota dan Daerah. 3(1): 11-18. Retrieved July 30, 2018, from tatakota.ub.ac.id/index.php/tatakota/arti cle/view/117

Jeon, Y. H. (2004). The Application of Grounded Theory and Symbolic Interactionism. Scan J Caring Sci. 18: 249-256. doi:10.1111/j.1471-6712.2004.00287.x

Jiménez, P. K. (2018). Exploring Students' Perceptions About English Learning in A Public University. HOW. 25(1): 69-91. https://doi.org/10.19183/how.25.1.385

Kim, B. (2001). Social constructivism. In M. Orey (Ed.)Emerging Perspectives on Learning, Teaching, And Technology (pp. 55-61). Zurich, Switzerland: Global Text.

LeCompte, M. D. and Schensul, J. J. (2010). Designing and Conducting Ethnographic Research: An Introduction (Ethnographer's Toolkit, Book 1). Plymouth: AltaMira Press. . (2013). Essential Ethnographic Methods (Ethnographer's Toolkit, Book 3). Plymouth: AltaMira Press.

Lichtman, R. (1970). Symbolic Interactionism and Social Reality: Some Marxist Queries. Berkeley Journal of Sociology. 15: 75-94. doi:10.2307/41035170

Lodico, M. G., Spaulding, D. T. \&Voegti, K. H. (2010). Methods in educational research: From theory to practice $\left(2^{\text {nd }} \mathrm{E}\right.$ d.). San Francisco: John Wiley \& Sons, Inc.

Miles, M. B., Huberman, A. M., \& Saldana, J. (2013). Qualitative Data Analysis: A Methods Sourcebook ( $3^{\text {rd }} E$ d.). Thousand Oaks, California: Sage Publications, Inc.

Onuf, N. (2012). Making Sense, Making Worlds: Constructivism in Social Theory and International Relation. New York, NY: Routledge.

Perez-Gore, I., McCormick, R., Burton, S., and Siddique, Md. A. (2014). Perceptions of English Language Learning and Teaching among Primary and Secondary Teachers and Students Participating in English in Action: Second Cohort (2013). English in Action, Dhaka, Bangladesh. Retrieved July 21, 2018, from http://oro.open.ac.uk/42302/

Rothbauer, P. M. (2008). Social Constructionism. In L. M. Given (Ed.)The sage encyclopedia of qualitative research methods (Vols. 1-2) (pp. 892-894). California: Sage Publication, Inc.

Searle, J. R. (1995). The Social Construction of Reality. New York, NY: The Free Press. 
Setiawan, A. W. (2015). Attitudes towards Indonesian teachers of English and Implication for their professional identity. A Doctoral Thesis. University of Adelaide.Retrieved July 30, 2018, fromhttps://digital.library.adelaide.edu.au/dspace/bitstream/2440/98639/2/02whole.p df

Shenton, K. A. (2004). Strategies for Ensuring Trustworthiness in Qualitative Project. Education for Information. 22(2): 63-75.doi:10.3233/EFI-2004-22201

Wells, G. (2002). Learning and Teaching for Understanding: The Key Role of Collaborative Knowledge Building. In J. Brophy (Ed.) Social Constructivist Teaching: Affordances and Constraints (pp. 1-41). Amsterdam: Elsevier Science Ltd.

Zacharias, N. T.(2003). A survey of tertiary teachers' beliefs about English Language Teaching in Indonesia with regard to the role of English as a global language. A Thesis. Assumption University of Thailand. Retrieved July 20, 2018, fromhttps://www.asian-efljournal.com/2327/thesis/a-survey-of-tertiary-teachers-beliefs-about-english-languageteaching-in-indonesia-with-regard-to-the-role-of-english-as-a-global-language/\#squelchtaas-tab-content- $0-3$

\section{Appendix 1}

Interview Main Questions

1. How does the learners' learning experience prior their learning in Kampung Inggris shape their perception on English?

In answering this question, the researcher addressed some questions related to the nature of the students and their perception on English. The questions about the students' nature included the students' demographic information, and motivations in learning English. The questions related about their initial perception were about English as a language, the importance of English, and the language learning process experienced by them before coming to Kampung Inggris.

\section{Appendix 2}

Interview notes

Full interview notes can be downloaded throughhttps://drive.google.com/open?id=1WyId8MCrjMZ6Q6Usp3K-imZhp2VvCvt

\section{Appendix 3}

Interview Transcripts (after data condensation)

Full interview transcripts can be downloaded through

https://drive.google.com/open?id=13prQ4FU5yrmg7 X-K-Hx MW2ji_8zJn3 


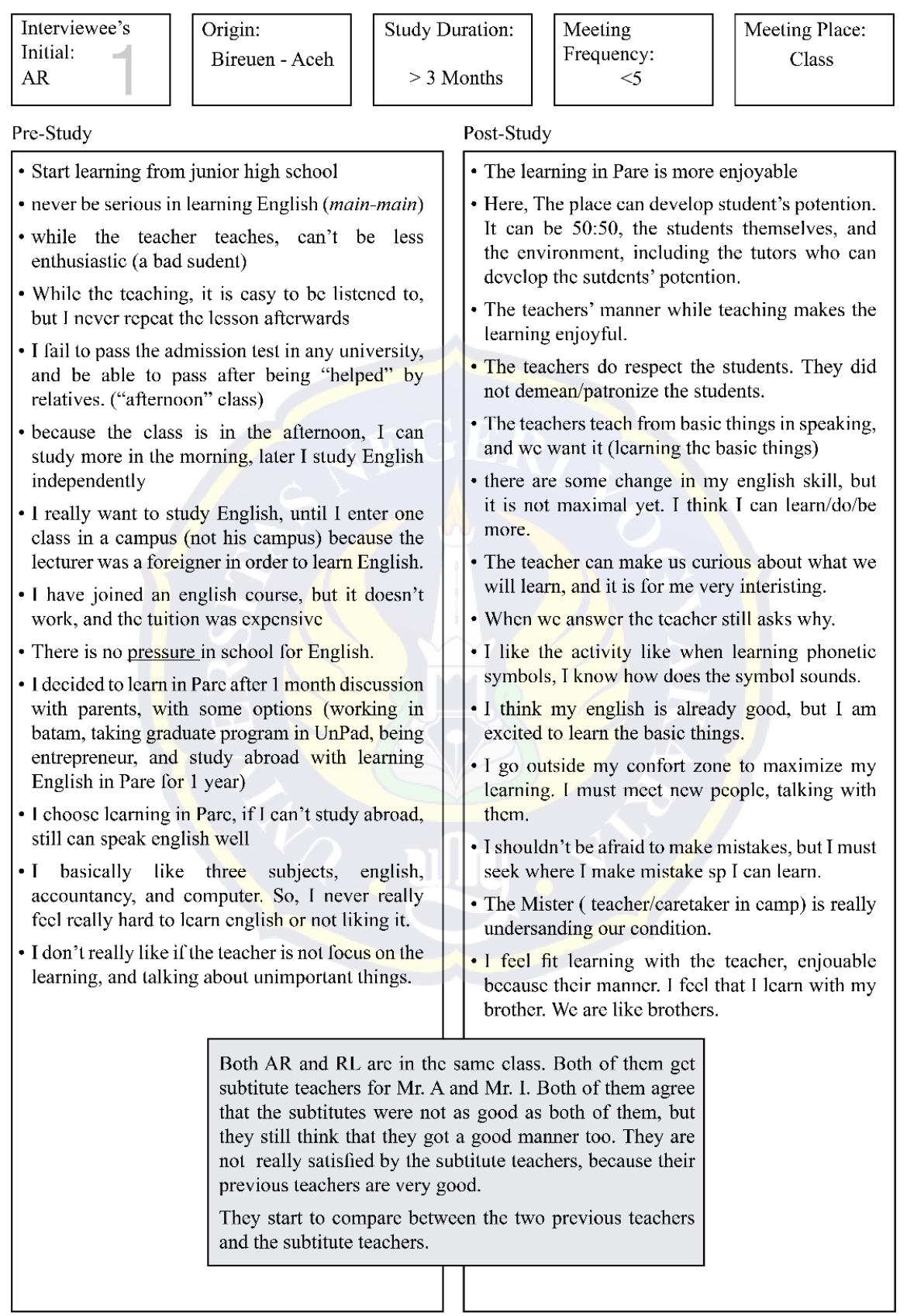

\section{Appendix 4}

\section{Interview Recording File}

The interview recording file can acquired through

\section{https://drive.google.com/open?id=1tdDvgcabmgex8LrQhjE62MkGR-XnZmqR}

